\title{
DINAMIKA ZAKAT DAN URGENSINYA DALAM ALQURAN DAN HADITS
}

\author{
Irwanuddin \\ UIN Alauddin Makassar \\ Email: irwanuddinuinmakassar@gmail.com
}

\begin{abstract}
Abstrak
Zakat merupakan rukun Islam yang ke lima yang berarti bahwa zakat hal yang penting dalam Islam. Salah satu bukti bahwa zakat merupakan hal yang penting dalam Islam adalah peristiwa yang terjadi di masa khalifah Abu Bakar yang memerangi kelompok yang tidak ingin membayar zakat. Zakat dalam Islam dianggap sangat penting oleh karena terkait dengan masalah ekonomi umat Islam. Salah satu upaya untuk menumbuhkan ekonomi umat adalah melalui zakat sehingga zakat memegang peranan penting di dalam ajaran Islam. Pendekatan yang digunakan dalam tulisan ini adalah metode pendekatan teks, baik dalam teknik interpretasinya maupun dalam analisisnya, namun terkadang meggunakan interpretasi secara interkteks dengan alasan hadis Rasulullah adalah personifikasi dan penjelas Alquran.
\end{abstract}

Keyword: zakat, urgensi, alquran dan hadits

\section{PENDAHULUAN}

Sejak empat belas tahun yang silam, Islam telah mengatur dan membimbing manusia di persada bumi ini agar dapat meraih kebahagiaan yang dapat dinikmati dalam kehidupan dunia dan kebahagiaan yang abadi di akhirat kelak nanti. Untuk mencapai kebahagiaan tersebut, Allah memberi manusia petunjuk dan pedoman dan tolak ukur dalam setiap prilaku, tindakan dan pekerjaan apa saja, baik yang terkait dengan kehidupan dunia maupun yang berhubungan dengan akhirat. Petunjuk tersebut ada yang langsung dari Allah dan ada pula melalui utusannya dan itulah yang disebut al-Qur'an dan Sunnah Rasulullah yang dapat menjamin seseorang tidak akan tersesat selamanya ${ }^{1}$.

Di antara masalah kehidupan yang diatur al-Qur'an dan Sunnah Rasulullah adalah tata kehidupan sosial dan di antara pranata sosial yang diatur oleh keduanya adalah zakat yang merupakan ajaran pokok, bahkan menjadi salah satu azaz Islam yang sama pentingnya dengan shalat, puasa dan haji. ${ }^{2}$ Itulah sebabnya, pekerjaan pertama yang dilakukan oleh Abu Bakar alShiddiq setelah diangkat menjadi khalifah pertama adalah memerangi orang-orang yang enggan menunaikan zakat.

Meskipun zakat sebagai sebuah ibadah yang menyangkut harta benda dan berfungsi sebagai ibadah sosial sudah dikenal jauh sebelum Islam muncul yang diperkenalkan oleh para rasul terdahulu, bahkan termasuk ibadah yang berumur tua, ${ }^{3}$ namun banyak di antara kaum muslimin tidak pahan dan tidak mengerti tentang zakat itu sendiri, baik yang terkait dengan hukum, jenis, syarat, bentuk pelaksanaan dan orang-orang yang berhak mendapatkannya. Ketidaktahuan masyarakat Islam, terkadang dipengaruhi oleh kurangnya inforamasi kepada mereka, baik melalui media massa, elektronik maupun melalui para da'i, bahkan melalui bukubuku bacaan atau karena kurangnya kesadaran mereka terhadap zakat.

\footnotetext{
${ }^{1}$ Abu Isa al-Turmudzi, Sunan al-Turmudzi, (Bairut: Dar Ihya' al-Turats al-Araby) Jilid 5: 662

2 Lihat Muhammad bin Ismail al-Bukhari, Shahih al-Bukhari, (Bairut: Dar Ibnu Katsir, 1987) Jilid 1:12

${ }^{3}$ Lihat al-Qur'an Surah al-Anbiya' ayat 73 dan Azyumardi Azra, Ed. Ensiklopedi Islam, (Jakarta: Ichtiar Baru van Hoeve) h. 312
} 
Diwajibkannya zakat, seharusnya dimanfaatkan sebaik mungkin sebab dengan zakatlah masyarakat kalangan bawah merasa terayomi dan diperhatikan oleh mereka-mereka yang kebetulan diberi rizki yang melimpah, bukan malah sebaliknya menjadi jurang pemisah antara sikaya dan simiskin. Padahal dengan zakat, baik zakat al-mal maupun zakat al-fitrah, kebutuhan masyarakat dapat sedikit dipenuhi dan penderitaan serta beban mereka dapat diringankan.

Zakat fitrah misalnya, jika setiap orang di seluruh Indonesia mengeluarkan zakat fitrah 5000 saja setiap kepala maka dapat dipastikan dana yang terkumpul dari zakat ini saja sebanyak Rp. 1.000.000.000.000-, (satu triyun rupiah) dengan asumsi jumlah penduduk adalah 200.000.000-, (dua ratus juta). Dana sebanyak ini hanya diperoleh dari zakat fitrah saja, bagaimana dengan zakat mal yang lebih besar lagi. Sekali lagi sangat dibutuhkan kesadaran masyarakat tentang pentingnya menunaikan zakat dan manfaat yang akan diperoleh.

Kesadaran dan pemahaman itu bisa muncul jika pemerintah dapat mengatur dan mengelola dengan profesional dan transparan. Di samping itu, para ulama, intelektual dan da'i dituntut untuk memahami betul hal-hal yang terkait dengan zakat sehingga nantinya dapat menyampaikan azaz Islam yang satu ini ke tengah-tengah masyarakat dengan benar dan tepat.

Salah satu cara untuk memperoleh pemahaman yang baik dan tepat tentang zakat adalah melalui kajian yang komprehensip terhadap kitab yang menjadi pedoman umat Islam itu sendiri yaitu al-Qur'an dan Sunnah Rasulullah. Oleh karena itu, melalui makalah ini, penulis mencoba menguraikan tentang zakat dari perspektif hadis Rasulullah dengan metode maudhu'i (tematik).

\section{Kajian Pustaka}

Tulisan ini ditulis dengan merujuk kepada beberapa sumber terkemuka yakni Alquran, kitab Shahih Bukhari, Shahih Muslim serta kitab-kitab imam-imam terkemuka seperti Abu Daud, Nasai, Ahmad Bin Hanbal dan beberapa kitab lain. Selain itu, dirujuk pula buku tulisan Azyumardi Azra yang berjudul Ensiklopedia Islam.

\section{METODE PENELITIAN}

Dalam tulisan ini, penulis menggunakan metode pendekatan teks, baik dalam teknik interpretasinya maupun dalam analisisnya, namun terkadang meggunakan interpretasi secara interkteks dengan alasan hadis Rasulullah adalah personifikasi dan penjelas Alquran.

\section{HASIL DAN PEMBAHASAN}

Kata zakat berasal dari bahasa Arab yang mengandung banyak arti, antara lain keberkahan, kesuburan, kesucian dan kebaikan. ${ }^{4}$ Namun maknanya secara harfiyah seperti yang tertulis dalam Fiqh al-Islam wa Adillatuh ${ }^{5}$ adalah berkembang-biak dan bertambah, namun terkadang digunakan pada makna "kesucian", sebagaimana dalam surah al-Syams ayat 9 atau bermakna "pujian". ${ }^{6}$ Dari sini dapat dipahami bahwa menunaikan zakat pada dasarnya akan menambah jumlah harta benda atau menjadikan harta benda itu subur, berkembang, suci dan baik, sedangkan orang yang menunaikan zakat akan tergolong orang-orang yang banyak berbuat baik dan duji oleh semua orang. Penamaan dari segi etimologi ini sejalan dengan firman Allah dalam surah al-Taubah ayat 103:

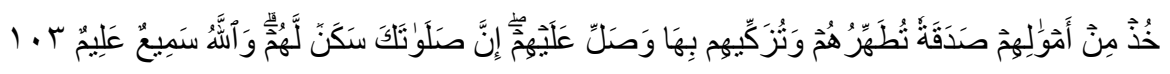

Terjemahnya:

\footnotetext{
${ }^{4}$ Muhammad Baqir al-Habsyi, Fiqih Praktis 1 menurut al-Qur'an, al-Sunnah dan Pendapat Ulama, (Bandung: PT Mizan Pustaka, 2005) h. 273.

${ }^{5}$ Wahbah Zuhaily, al-Fiqh al-Islamy wa Adillatuh, (Bairut: Dar al-Fikr, 1997) Jilid 3: 1788.

${ }^{6}$ Lihat al-Qur'an al-Karim, Surah al-A'la ayat 14.
} 
Ambillah zakat dari sebagian harta mereka, dengan zakat itu kamu membersihkan dan mensucikan mereka dan mendoalah untuk mereka. Sesungguhnya doa kamu itu (menjadi) ketenteraman jiwa bagi mereka. Dan Allah Maha Mendengar lagi Maha Mengetahui (QS. Al-Taubah; 103) ${ }^{7}$

Zakat secara terminologi adalah hak wajib yang terdapat dalam harta benda. Para ulama madzhab beragam dalam memberi definisi. Madzhab Maliki misalnya mendefinisikan zakat dengan "Menunaikan sebagian harta tertentu yang sudah mencapai satu nisab kepada orangorang yang berhak jika harta itu milik mutlak dan sudah mencapai satu tahun". Madzhab Hanafi mengartikannya dengan "Memilikkan sebagian harta tertentu kepada orang-orang tertentu yang telah ditentukan oleh syari' (Allah dan Rasul-Nya) karena Allah swt. Untuk madzhab Syafi'i, mereka memberi definisi "Nama sesuatu yang dikeluarkan, baik yang terkait dengan harta atau badan dengan cara tertentu". Sedangkan madzhab Hambali mengatakan "Zakat adalah Hak wajib yang ada dalam harta benda untuk orang-orang tertentu pada waktu tertentu pula". ${ }^{8}$ Dari sekian banyak definisi yang diutarakan para ulama, dapat disimpulkan bahwa zakat itu harus memenuhi beberapa unsur, antara lain:

- Hak yang wajib ditunaikan

- Harta yang dizakati telah ditentukan oleh syara'

- Orang-orang yang berhak mendapatkan zakat juga telah ditentukan.

- Waktu penunaian zakat juga sudah ditetapkan oleh syara'

- Syarat-syarat lain seperti mencapai ukuran wajibnya zakat, milik mutlak dan sudah mencapai satu tahun.

Dari dua definisi ini, dapat dipahami bahwa zakat sebenarnya sangat besar manfaatnya dalam kehidupan manusia, khususnya di bidang sosial. Karena dengan zakat, orang-orang lemah bisa memperoleh bantuan dari sikaya dan sikaya dapat mengembangkan, membersihkan, menyuburkan harta bendanya, apatah lagi tidak semua harta wajib ditunaikan zakatnya. Menunaikan zakat merupakan hal yang wajib sesuai hadits Rasulullah saw.

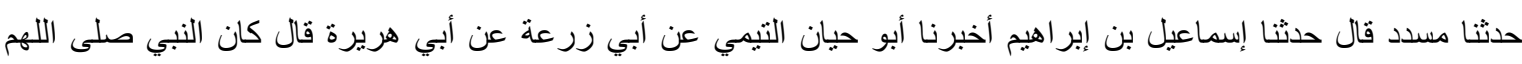

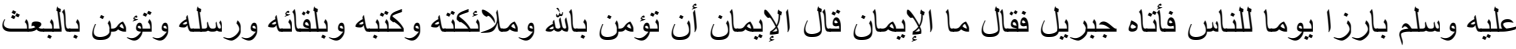

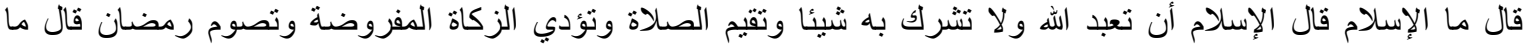

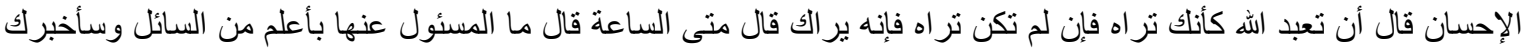

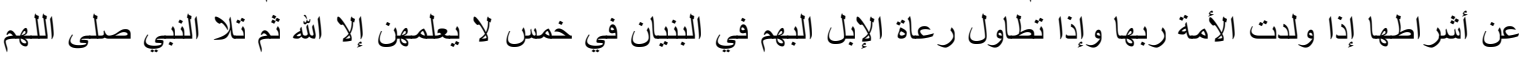

$$
\begin{aligned}
& \text { عليه وسلم (إن الله عنده علم الساعة) الآية الخ..9 }
\end{aligned}
$$

Terjemahnya:

Dari Abu Hurairah berkata "Rasulullah suatu tampak bersama-sama dengan sahabatsahabatnya, lalu Jibril mendatanginya seraya bertanya "Apa itu Iman?", Rasulullah menjawab "Iman adalah percaya kepad Allah, para malaikat, kitab-kitab, bertemu Allah, para rasul dan percaya pada hari kebangkitan", dia bertanya lagi "Apa itu Islam"?, Rasulullah menjawab "Islam adalah Anda menyembah Allah dan tidak menyekutukannya dengan apapun, mendirikan shalat, menunaikan zakat wajib, berpuasa Ramadhan, lalu dia

\footnotetext{
${ }^{7}$ Meskipun dalam ayat ini, Allah menggunakan kata shadaqah, namun bukan berarti yang dimaksud adalah sedekah karena al-Qur'an dan hadis Rasulullah memang seringkali menggunakan kata shadaqah untuk makna zakat. Untuk membedakan mana yang bermakna zakat dan mana yang bermakna sedekah, harus dilihat dari teks dan konteks dalil itu berada/muncul.

${ }^{8}$ Wahbah Zuhaily, al-Fiqh al-Islamy wa Adillatuh, Op.Cit. Jilid 3: 1788-1789

${ }^{9}$ Teks hadis ini dan yang semakna terdapat dalam 3 kitab yaitu Muhammad bin Ismail, Shahih al-Bukhari, Kitab al-Iman, bab Suali Jibril al-Nabiyy, Op.Cit. Jilid 1: 27, Muslim bin al-Hajjaj al-Naisaburi, Shahih Muslim, kitab al-Iman, bab Bayan al-Iman, al-Islam, alIhsan (Barut: Dar Ihya' al-Turats al-Araby) Jilid: 1: 39 dan Ahmad bin Hambal, Musnad Ahmad, Musnad Abi Hurairah, (Kairo: Muassasah Qurthubah) Jilid 2: 342.
} 
bertanya lagi "Apa itu Ihsan?" Rasulullah menjawab "Ihsan adalah engkau menyembah Allah layaknya engkau melihat-Nya, jika engkau tidak dapat melihat-Nya, maka Allah melihatmu" lalu dia masih bertanya "Kapan hari kiamat?" Rasulullah berkata "Orang yang ditanya tidaklah lebih tahu di banding sipenanya, akan tetapi aku akan mengkabarkan tentang tanda-tandanya, Jika seorang budak melahirkan tuannya, jika para pengembala unta berbangga-banggaan akan bangunannya, ...(HR. Bukhari)

Adapun jenis-jenis harta yang wajib dizakati sesuai hadits Rasulullah saw.

حدثنا سليمان بن داود المهري أخبرنا ابن وهب أخبرني جرير بن حازم وسمى آخر عن أبي إسحق عن عاصم بن ضمرة

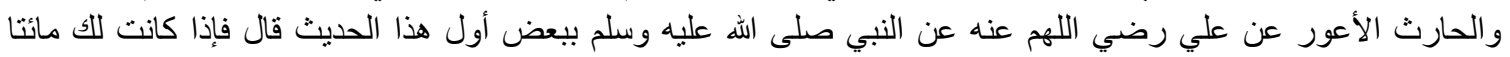

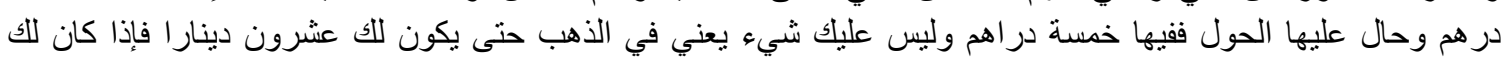

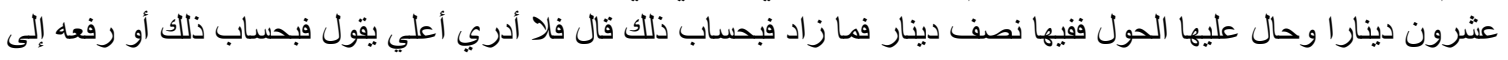

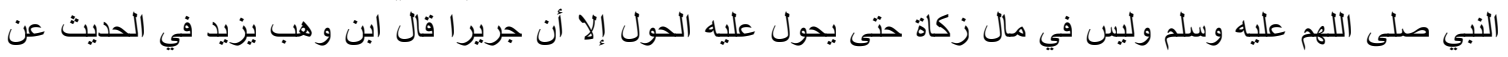

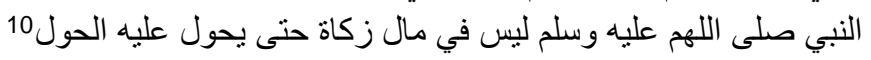

Terjemahnya:

Dari Ali bin Abi Thalib dari Rasulullah bersabda "Jika engkau memiliki 200 dirham dan sudah mencapai satu tahun, maka wajib bayar zakat sebanyak 5 dirham, dan engkau tidak berkewajiban menunaikan zakat dinar sehingga mencapai 20 dinar.Jika mencapai 20 dinar maka zakatnya adalah setengah dinar, sedang lebihnya sesuai dengan hitungannya".

Selanjutnya, orang-orang yang berhak menerima zakat, waktu pelaksanaan zakat serta ancaman bagi penentangnya sesuai hadits Rasulullah saw.

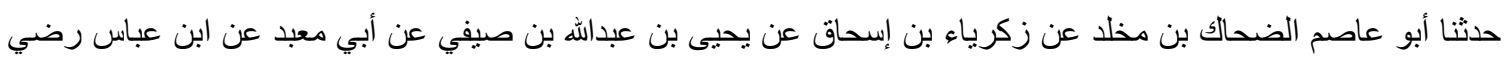

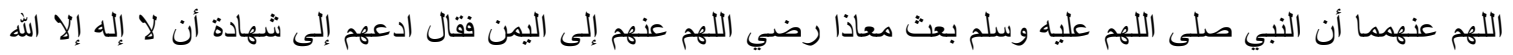

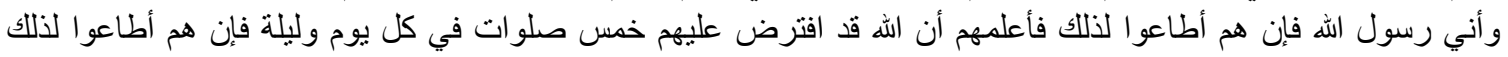

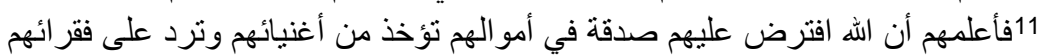

Terjemahnya:

Dari Abdullah bin Abbas, Rasulullah mengutus Mu'adz Bin Jabal ke negara Yaman seraya bersabda "Ajkalah mereka untuk bersaksi bahwa tiada Tuhan selain Allah dan Aku adalah utusan-Nya. Jika mereka mematuhinya, beritahukan mereka bahwa Allah mewajibkan zakat harta yang diambil dari kalangan kaya dan dikembalikan kepada kalangan tidak mampu

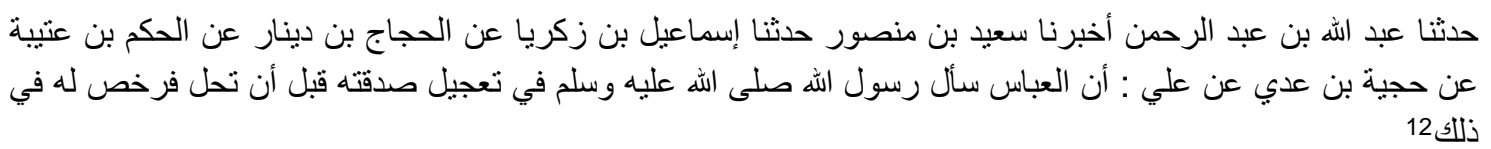

${ }^{10}$ Malik bin Anas, Muwattha' Malik Kitab al-Zakat Bab Zakat al-Mal (Damaskus: Dar al-Qalam, 1991) Jilid 2: 116 dan Sunan Abi Daud Kitab al-Zakat Bab Fi Zakat al-Saimah Op.Cit. Jilid 1: 493

${ }^{11}$ Naskah hadisnya diambil dari Shahih al-Bukhari, Kitab al-Zakat Bab Wujub al-Zakat, Op.Cit. Jilid 2:505, akan tetapi matan yang sama juga terdapat dalam Sunan Abi Daud, Kitab al-Zakat Bab Fi Zakat al-Saimah, Op.Cit. Jilid 1:498, Sunan al-Turmudzi, Kitab alZakat Bab Karahiyah akhdzi Khiyar al-Mal, Op.Cit. Jilid 3:21, Sunan al-Nasay, Kitab al-Zakat, Bab Ikhraj al-Zakat min Balad, ,Op.Cit. Jilid 5:55, Sunan Ibnu Majah, Kitab al-Zakat, BabFardh al-Zakat, Op.Cit. Jilid 1:578. Musnad Ahmad, MusnadAbdullah bin Abbas, Op.Cit Jilid 1:233 dan Abdullah bin Abd Rahman, Sunan al-Darimi, Kitab al-Zakat Bab FI Fadhl al-Zakat, (Bairut: Dar al-Kutub alAraby, 1407 H) Jilid 1:461.

${ }^{12}$ Sunan al-Turmudzi, Kitab al-Zakat Bab Karahiyah akhdzi Khiyar al-Mal, Op.Cit. Jilid 3:21, Sunan al-Nasay, Kitab al-Zakat, Bab Ikhraj al-Zakat min Balad, ,Op.Cit. Jilid 5:55, Sunan Ibnu Majah, Kitab al-Zakat, BabFardh al-Zakat, Op.Cit. Jilid 1:578. Musnad Ahmad, MusnadAbdullah bin Abbas, Op.Cit Jilid 1:233 
Terjemahnya:

Dari Ali bin Abi Thalib, bahwa "Abbas pernah bertanya tentang mempercepat zakat sebelum sampai waktunya, lalu Rasulullah mengizinkannya”...

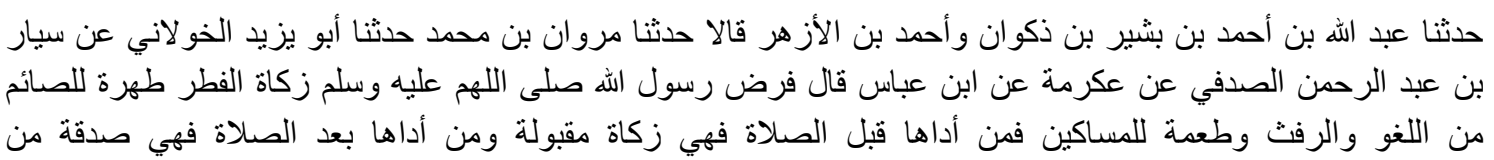
الصدقات13

Terjemahnya:

Dari Abdullah bin Abbas Allah mewajibkan zakat fitrah sebagai penyucian bagi orangorang yang berpuasa dari ucapan sia-sia dan kotor dan memberi makan orang miskin. Barang siapa yang menunaikannya sebelum shalat (idul fitri) maka termasuk zakat yang diterima dan barang siapa yang menunaikannya setelah shalat maka termasuk sedekah.

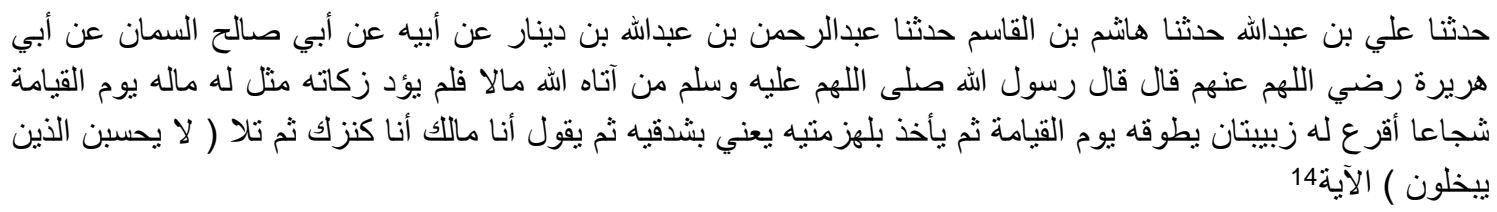

Terjemahannya:

Dari Abi Hurairah berkata, Rasulullah bersabda "barang siapa yang dikaruniai oleh Allah harta benda lalu tidak menunaikan zakatnya, maka kelak pada hari kiamat, hartanya akan diserupakan ular besar yang penuh dengan racun mematikan, di atas matanya ada dua titik yang mengerikan, kemudian ular itu dengan kuatnya, mencengkramkan kedua rahangnya kemudian berkata "Akulah hartamu, akulah harta yang kau timbun" kemudian Rasulullah membaca Surah Ali Imran ayat 180.

Dari beberapa hadits tersebut, sudah jelas bahwa zakat merupakan hal yang wajib dilaksanakan sehingga bagi yang tidak menunaikannya diberikan ancaman berupa siksa di hari kiamat.

Zakat merupakan salah satu azaz yang terpenting dalam Islam, sehingga Abu Bakar mengatakan "Demi Allah, Aku akan memerangi orang yang membedakan antara kewajiban zakat dengan kewajiban shalat". ${ }^{15}$ Zakat yang diwajibkan dalam Islam ada dua yaitu zakat mal dan zakat fitrah.

Kata "zakat" yang yang tidak diikutkan dengan kata "fitrah" atau "ramadhan" maka yang dimaksud adalah adalah zakat mal, baik kata itu terdapat dalam al-Qur'an maupun hadis Rasulullah. Sedangkan kata yang menunjukkan zakat fitrah lebih banyak menggunakan زكاة الفطر, صدقة الفطر dan Dalam Alquran, kata zakat yang digandengkan dengan kata shalat sekitar 82 kali ayat. ${ }^{16}$ Hal ini menunjukkan bahwa zakat mal dan zakat fitrah amatlah penting, bahkan sejajar dengan shalat.

\footnotetext{
${ }^{13}$ Teksnya disadur dari Sunan Ibnu Majah, Kitab al-Zakat, BabShadaqah al-Fithrit, Op.Cit. Jilid 1:585, akan tetapi terdapat juga dalam Sunan Abi Daud, Kitab al-Zakat Bab Zakat al-Fithri, Op.Cit. Jilid 1:505.

${ }^{14}$ Naskah hadisnya diambil dari Shahih al-Bukhari, Kitab al-Zakat Bab Itsm Mani' al-Zakat, Op.Cit. Jilid 2:508, akan tetapi matan yang sama juga terdapat dalam Sunan al-Nasay, Kitab al-Zakat, Bab Mani' Zakat Malih,Op.Cit. Jilid 5:38, Musnad Ahmad, MusnadAbdullah bin Umar, Op.Cit Jilid 2:98 dan Muwattha' Malik Kitab al-Zakat Bab Ma jaa fi al-Kanz, Op.Cit. Jilid 1: 256.

15 Wahbah Zuhaili, Op.Cit. Jilid 3: 1794.

${ }^{16}$ Sayyid Sabiq, Fiqh al-Sunnah, (Kairo: Dar al-Tsaqafah al-Islamiyah) Jilid 1: 235.
} 
Zakat dengan kedua pembagiannya, disyariatkan atau diundangkan di Madinah pada bulan syawwal pada tahun keduan hijriyah. ${ }^{17}$ Sedangkan dalil-dalil yang menunjukkan wajib zakat adalah al-Qur'an, hadis dan ijma' ulama.

Zakat mal misalnya, hukumnya wajib berdasarkan al-Qur'an, hadis Rasulullah dan ijma' ulama. Di antara ayat al-Qur'an yang mewajibkan zakat adalah Surah al-Baqarah ayat 43, alTaubah ayat 103, al-An'am ayat 141 dan masih banyak lagi ayat-ayat yang mengindikasikan kewajiban zakat, baik secara tersurat maupun tersirat. Sedangkan hadis yang secara jelas mengungkapkannya adalah hadis yang diriwayatkan oleh Abu Hurairah (lihat hadis nomor 1 di atas) dan masih banyak lagi hadis-hadis yang mengungkapkan hal itu seperti hadis Abdullah bin Umar bahwa Islam dibangun atas lima pondasi, 18 pesan Rasulullah kepada Muadz bin Jabal ketika dikirim ke Yaman (lihat hadis nomor 6). Sahabat dan ulama-ulama setelahnya sepakat bahwa zakat mal wajib ditunaikan bahkan orang yang menentang kewajiban zakat harus diperangi sebagaimana yang dilakukan oleh Abu Bakar al-Shiddiq.

Sedangkan zakat fitrah wajib berdasarkan keumuman ayat-ayat al-Qur'an tentang wajib zakat dan hadis-hadis Rasulullah. Di antara hadis-hadis tersebut adalah hadis nomor 2 di atas, hadis taqriri riwayat Abu Said, ${ }^{19}$, hadis Ibnu Abbas (lihat hadis nomor 8), hadis Abdullah bin Tsa'labah. ${ }^{20}$

Pada awal Islam, harta yang menjadi kebanggaan dan kekayaan hanya terbatas pada hewan ternak, pertanian, perdagangan, buah-buahan, perhiasan emas dan perak. Namun di era yang modern ini, harta kekayaan tidak lagi terbatas pada harta tersebut, melainkan sudah mencakup berbagai sektor seperti jasa, penghasilan, gaji, profesi dan badan-badan usaha yang lain. Jika zakat hanya dibatasi berdasarkan teks hadis dan kondisi Rasulullah dan sahabatnya, tanpa mau menelaah, mengkaji hadis-hadis yang bersifat umum, maka hal itu akan memicu ketidakadilan dan ketidakseimbangan dalam masyarakat karena pada saat ini, banyak jenis harta benda yang lebih berpotensi wajib zakat dibanding dengan harta-harta yang terdapat pada masa Rasulullah. Untuk itu, penulis akan menjelaskan harta-harta wajib zakat berdasarkan hadis Rasulullah.

\section{Zakat Emas dan Perak}

Emas dan perak adalah harta yang wajib zakat berdasarkan al-Qur'an dan hadis Rasulullah. ${ }^{21}$ Sedangkan ukuran nisab emas yang wajib zakat berdasarkan hadis nomor 3 adalah 20 dinar atau sekitar 90 gram. ${ }^{22}$ Jika seseorang sudah memilik harta sekitar 90 gram atau lebih maka wajib zakat sebanyak setengah dinar atau lebih tepatnya 2,5\% dari jumlah emas yang dimilikinya. Sedangkan perak wajib zakat kalau mecapai 200 dirham atau setara dengan 672 gram perak, bahkan Muhammad Baqir al-Habsyi mengatakan 200 dirham itu kurang lebih 595 gram. ${ }^{23}$ dan zakatnya sama dengan emas yaitu 2,5 \% dari perak yang dimiliknya. Sebagian ulama menqiyaskan uang rupiah atau uang apa saja dengan nisab emas. Jadi seseorang yang memiliki uang senilai 90 gram emas atau 672 gram perak maka orang tersebut wajib zakat 2,5\%.

\footnotetext{
${ }^{17}$ Wahbah Zuhaili, Op.Cit. Jilid 3: 1792.

${ }^{18}$ Lihat Shahih al-Bukhari, Kitab al-Zakat Bab al-Iman wa Qaul al-Nabiy, Op.Cit. Jilid 1:12.

${ }^{19}$ Ibid. Jilid 2: 548.

${ }^{20}$ Musnad Ahmad, Op.Cit. Jilid 5: 432.

${ }^{21}$ Lihat al-Qur'an al-Karim Surah al-Nisa' ayat 34-35 dan hadis nomor 3.

${ }^{22}$ Ensiklopedi Islam, Op.Cit. h. 313 akan tetapi dalam buku Fiqih Praktis 1, karangan Muhammad Baqir al-Habsyi (Bandung: Mizan Pustaka, 2005) h. 281 dijelaskan bahwa 20 dinar sama dengan 85 gram.

${ }^{23}$ Muhammad Baqir al-Habsyi, Ibid. 281.
} 


\section{Zakat Hewan Ternak}

Hewan ternak adalah salah satu harta yang wajib zakat berdasarkan hadis Rasulullah saw. ${ }^{24}$ dan surat Abu Bakar kepada Anas bin Malik ketika diutus ke Bahrain ${ }^{25}$. Adapun hewanhewan yang wajib zakat unta (sama dengan unta lembu), sapi (sama dengan sapi kerbau), dan kambing. Mayoritas ulama fiqhi memberi syarat atau ketentuan tentang zakat hewan ternak, di antaranya harus berupa hewan ternak (bukan hewan liar), mencapai satu nisab selama satu tahun, dll. Tentang jumlah minimal hewan sehigga wajib zakat, baik unta, sapi maupun kambing banyak dijelaskan oleh hadis-hadis Rasulullah ${ }^{26}$. Akan tetapi jika melihat hadis Rasulullah bahwa "Tidak wajib bagi orang muslim mengeluarkan zakat budak dan kudanya" 27 dapat dipahami bahwa semua hewan ternak yang sengaja dipelihara untuk keperluan usaha, seperti keledai, rusa, ayam termasuk hewan wajib zakat.

\section{Zakat Pertanian}

Zakat pertanian wajib berdasarkan al-Qur'an dan hadis Rasulullah. ${ }^{28}$ Sedangkan jenis-jenis tanaman yang wajib zakat, ulama berbeda pendapat, sebagian mereka hanya membatasi pada lahir teks hadis Rasulullah sedangkan sebagian yang lain mengambil keumuman kandungan alQur'an dan hadis Rasulullah. Atas dasar pemahaman hadis nomor 5 di atas menurut hemat penulis, semua bentuk pertanian (sawah atau kebun) yang sengaja dikelolah (tidak tumbuh sendiri) dan dapat menghasilkan keuntungan melebihi kebutuhan sehari-hari termasuk harta yang wajib zakat. Mengenai jumlah minimal hasil pertanian yang wajib zakat adalah lima ausuq ${ }^{29}$ atau setara dengan $653 \mathrm{~kg}$ atau yang senilai dengannya dan lebih lengkapnya lihat kitabkitab fiqhi. Sedangkan jumlah zakat yang harus dikeluarkan sebanyak $10 \%$ jika pertanian itu tidak memakai biaya pengelolaan dan $5 \%$ dari hasil pertanian tersebut jika membutuhkan pembiayaan dalam pengelolaannya. ${ }^{30}$

\section{Perdagangan}

Hasil perdagangan termasuk harta yang wajib zakat berdasarkan al-Qur'an surah albaqarah ayat 267, al-Dzariyat ayat 19, al-Ma'arij ayat 24-25 dan hadis Rasulullah saw. (lihat hadis nomor 4) ${ }^{31}$. Mengenai jumlah minimal hasil zakat yang wajib zakat mengikuti ukuran nisab emas dan perak.

\section{Zakat Profesi, Eksploitasi dan Investasi}

Melihat keumuman ayat-ayat al-Qur'an yang mewajibkan mengeluarkan sebagian dari rezki dan hadis-hadis yang memerintahkan untuk berzakat ${ }^{32}$ atau bersedekah serta mengedepankan kehati-hatian dalam mengamalkan ajaran-ajaran Islam, penulis memandang bahwa semua hasil usaha, apakah dalam bentuk eksploitasi, investasi atau profesi harus dikeluarkan zakatnya. Jumlah minimal hasil profesi atau investasi mengikuti jumlah minimal nisab emas dan perak. Begitu juga dengan kadar zakat yang wajib dikeluarkan.

\footnotetext{
${ }^{24}$ Lihat hadis nomor 6.

${ }^{25}$ Shahih al-Bukhari, Kitab al-Zakat Bab Zakat al-Ghanam, Op.Cit. Jilid 2: 527.

${ }^{26}$ Baca Fiqh al-Sunnah, Kitab al-Zakat Bab Zakat al-Hayawan, Op.Cit Jilid 1: 259.

27 Teks arabnya, lihat Shahih al-Bukhari, Kitab al-Zakat Bab Laisa 'ala al-Muslim fi Farasihi Shadaqah, Op.Cit. Jilid 2: 532 dan status hadisnya shahih, sanad dan matan.

${ }^{28}$ Buka al-Qur'an al-Karim Surah al-Baqarah ayat 267 dan al-An'am ayat 141 serta baca hadis nomor 5.

${ }^{29}$ Shahih al-Bukhari, Kitab al-Zakat Bab Laisa fima Duna Khmsah Ausuq, Op.Cit. Jilid 2: 529.

30 Lihat hadis nomor 5.

31 Ada sebagian ulama, khususnya madzhab al-Dzahiri dan sebagian sekte Syiah yang tidak mewajibkan zakat hasil perdagangan dengan dalih tidak terdapat dalam al-Qur'an secara tersurat, sedangkan hadis tentang zakat perdagangan dinalai dhaif oleh mereka namun sebagian besar ulama mewajibkan zakat perdagangan ini dengan dalil yang tertera dalam masalah ini.

32 Teks lengkap, lihat Shahih al-Bukhari, Kitab al-Zakat Bab 'Ala Kulli Muslim Shadaqah, Op.Cit. 2: 524.
} 
Orang yang berhak menerima zakat, khususnya zakat mal ${ }^{33}$ sudah ditetapkan dan ditentukan oleh al-Qur'an ${ }^{34}$ yang dikenal dengan istilah al-ashnaf al-Tsamaniyah (8 golongan) yaitu:

- Al-Fakir: mereka yang tidak memiliki harta atau pekerjaan yang bisa menghidupi dirinya. Senada dengan definisi tersebut, komentar Muhammad Abd Rasyid yang berkata "fakir adalah mereka yang tidak dapat menghidupi dirinya sendiri". 35

- Miskin adalah mereka yang dapat menghidupi dirinya sendiri akan tetapi tidak dapat menghidupi keluarganya ${ }^{36}$ atau orang yang penghasilannya tidak mencukupi kebutuhan hidupnya.

- Amil zakat yaitu orang-orang yang diangkat dan ditunjuk untuk bertugas mengumpulkan dan mendistribusikan zakat.

- Muallaf, orang-orang kafir yang diberi zakat agar masuk Islam ${ }^{37}$ atau orang Islam yang masih lemah imannya. ${ }^{38}$ Dam orang yang ingin berbuat jahat kepada Islam.

- Budak atau (tawanan perang) yang membutuhkan bantuan untuk dibebaskan.

- Al-Gharimin yaitu orang yang punya hutang karena desakan kebutuhan hidup atau orang yang berhutang karena ingin mendamaikan sengketa atau untuk jaminan. ${ }^{39}$

- Sabilillah adalah orang yang berjihad di jalan Allah atau semua bentuk pendekatan diri kepada Allah. Seperti dana dakwah, pembangunan pasilitas umum, tunjangan tenaga pengajar,dll.

- Ibnu al-Sabil adalah orang yang sedang melakukan perjalanan dan kehabisan bekal, akan tetapi perjalanannya untuk hal-hal yang positif, bukan perjalanan bertamasya atau melancong.

Delapan golongan yang telah disebutkan berlaku untuk zakat fitrah, sedangkan untuk zakat fitrah, sebagian ulama, khususnya Syiah ${ }^{40}$ berpendapat lain dengan mengakatakan bahwa zakat fitrah khusus diberikan kepada orang-orang yang tidak mampu, bukan kepada yang lain berdasarkan lahirnya hadis Rasulullah. ${ }^{41}$

Pemberian zakat kepada mustahiq-nya harus melihat kondisi masyarakat. Jika masyarakat sangat memerlukan bantuan segera untuk konsumtifnya maka zakat diberikan hanya sekedar menutupi kebutuhan tersebut. Namun perlu dikaji kembali pemberian yang bersifat konsumtif karena hal ini tidak menjamin masa depan dan pada akhirnya zakat tidak berfungsi secara maksimal. Oleh karena itu, pemerintah seharusnya tanggap untuk segera memberlakukan undang-undang zakat, khususnya yang terkait dengan pensdistribusiannya. Sehingga nantinya zakat dapat mengurangi angka kemiskinan dan menekan perbedaan sosial yang akhir-akhir ini semakin tajam.

Sesuai hadits dapat dipahami bahwa pada dasarnya batas waktu wajib zakat adalah setelah harta itu dimiliki selama setahun, namun boleh dipercepat atau bibayar perbulan dengan catatan bahwa jumlah harta benda tersebut mencapai minimal jumlah harta yang wajib zakat. Waktu ini berlaku untuk zakat mal.

\footnotetext{
33 Karena dalam zakat fitrah, ulama berbeda pendapat tentang orang yang berhak mendapatkannya.

34 Surah al-Taubah ayat 60.

35 Muhammad Abd Rasyid, Indeks al-Qur'an, (Yogyakarta: Diglossia Media Group, 2007) h. 463.

36 Ibid. 463.

37 Wahbah Zuhaili, Op.Cit. Jilid 3: 1998.

${ }^{38}$ Hal semacam ini berdasarkan hadis fi'ly Rasulullah pada saat memberi zakat kepada Abu Sufyan bin Harb, Shafwan bin Umayyah dan lain-lain. (lihat Wahbah Zuhaili, Jilid 3: 1998-1999.

${ }^{39}$ Ensiklopedi Islam, Op.Cit Jilid 7: 318.

40 Muhammad bin Ismail al-Shan'ani, Subul al-Salam, (Bandung: Dahlan) Jilid 2: 140.

${ }^{41}$ Baca hadis nomor 8.
} 
Sedangkan zakat fitrah waktunya sudah ditentukan dengan jelas oleh hadis Rasulullah ${ }^{42}$ yaitu harus ditunaikan sebelum shalat idul fitri, akan tetapi dengan adanya hadis dari al-Abbas (hadis nomor 7) menunjukkan bahwa boleh saja zakat fitrah dipercepat ditunaikan asalkan dalam suasana ramadhan.

Hikmah yang terkandung dalam pensyariatan zakat dan ancaman bagi penentangnya sudah dijelaskan oleh al-Qur'an dan hadis Rasullah saw. ${ }^{43}$ di antara hikmah-hikmah di syariatkan zakat adalah:

- Menjaga harta dari pandangan dan tangan-tangan orang jahat sebagaimana hadis Rasulullah ${ }^{44}$.

- Membantu orang-orang fakir dan miskin.

- Membersihkan diri dari kekikiran dan kebakhilan dan belas kasih kepada sesame.

- Mensykuri nikmat yang dikaruniakan Allah kepadanya.

Sedangkan ancaman bagi orang yang enggan menunaikan zakat dijelaskan secara gamblang oleh al-Qur'an dan hadis Rasulullah antara lain:

- Akan mendapatkan siksaan yang amat pedih (surah al-Taubah ayat 34-35)

- Hartanya akan dikalungkan di lehernya pada hari kiamat nanti (surah Ali Imran ayat 180)

- Hartanya akan berubah menjadi ular dan akan menyiksanya (lihat hadis nomot 9).

Dan masih banyak hadis-hadis yang menunjukkan ancaman bagi orang yang tidak mau menunaikan zakat., baik siksaan yang ada di dunia seperti diperangi ataupun siksaan di akhirat kelak.

\section{PENUTUP}

Zakat adalah hak wajib yang terdapat dalam harta benda tertentu, untuk orang-orang tertentu dengan cara dan waktu tertentu pula. Zakat itu juga terbagi dua, ada zakat mal dan ada zakat fitrah. Berdasarkan Alquran, hadis-hadis serta pendapat ulama yang telah dipaparkan di atas, maka dapat disimpulkan hal-hal seperti berikut.

- Menunaikan zakat hukumnya wajib, baik zakat mal maupun zakat fitrah

- Jenis-jenis harta wajib zakat adalah semua harta yang dapat memberi hasil, dapat tumbuh dan berkembang, serta usaha-usaha yang dapat memberikan penghasilan.

- Orang-orang yang berhak mendapatkan zakat adalah orang-orang yang masuk kategori alAshnaf al-Tsamaniyah (golongan 8 dalam surah al-Taubah ayat 60 ).

- Waktu menunaikan zakat mal setelah mencapai satu tahun kepemilikan dan cukup 1 nisab (batas minimal) jumlah harta wajib zakat. Sedangkan zakat fitrah ditunaikan harus sebelum shalat idul fitri, akan tetapi boleh dipercepat asalkan sudah dalam suasana ramadhan. Begitu juga zakat mal boleh dipercepat pembayarannya asalkan yakin mencapai satu nisab.

- Hikmah-hikmah disyariatkan zakat antara lain, membersihkan harta dan membantu orang yang kurang mampu atau membutuhkan bantuan. Sedangkan ancaman bagi orang yang tidak mau menunaikan zakat sangat keras, di dunia atau di akhirat.

\footnotetext{
${ }^{42}$ Lihat hadis nomor 8.

${ }^{43}$ Buka al-Qur'an al-Karim Surah al-Nahl ayat 71, al-Dzariyat ayat 19 dan hadis nomor 8.

${ }^{44}$ Sulaiman bin Ahmad al-Thabrani, Mu'jam al-Aushath li al-Thabrani, (Kairo: Dar al-Haramain, 1915 H) Jilid 2: 274. namun hadis ini dhaif.
} 


\section{DAFTAR PUSTAKA}

al-Qur'an al-Karim

Abd Rahman, Abdullah bin. Sunan al-Darimi. Bairut: Dar al-Kutub al-Araby, 1407 H Abd Rasyid, Muhammad. Indeks al-Qur'an. Yogyakarta: Diglossia Media Group, 2007. Anas, Malik bin. Muwattha' Malik. Damaskus: Dar al-Qalam, 1991. al-Atsqalany, Ibnu Hajar. Tahdzib al-Kamal. Bairut: Muassasah al-Risalah, 1980. . Taqrib al-Tahdzib. Suriah: Dar al-Rasyid, 1986. Tahdzib al-Tahdzib. Bairut: Dar al-Fikr, 1984

Azra, Azyumardi, Ed. Ensiklopedi Islam. Jakarta: Ichtiar Baru van Hoeve al-Bukhari, Ismail, Muhammad bin. Shahih al-Bukhari. Bairut: Dar Ibnu Katsir, 1987 al-Habsyi, Baqir, Muhammad. Fiqih Praktis 1 menurut al-Qur'an, al-Sunnah dan Pendapat Ulama. Bandung: PT Mizan Pustaka, 2005

Hambal, Ahmad bin. Musnad Ahmad. Kairo: Muassasah Qurthubah Ibnu Majah, al-Qazwini. Sunan Ibnu Majah. Bairut: Dar al-Fikr al-Naisaburi, al-Hajjaj, Muslim bin. Shahih Muslim. Barut: Dar Ihya' al-Turats al-Arab al-Nasay, Abu Abd Rahman. Sunan al-Nasay. Halb: Maktabah al-mathbu'ah al-Islamiyah, 1987. Sabiq, Sayyid. Fiqh al-Sunnah. Kairo: Dar al-Tsaqafah al-Islamiyah al-Sajastani, Abu Daud. Sunan Abi Daud. Bairut: Dar al-Fik al-Shan'ani, Ismail, Muhammad bin. Subul al-Salam. Bandung: Dahlan al-Thabrani, Ahmad, Sulaiman bin. Mu'jam al-Aushath li al-Thabrani. Kairo: Dar al-Haramain, $1915 \mathrm{H}$.

al-Turmudzi, Abu Isa. Sunan al-Turmudzi. Bairut: Dar Ihya' al-Turats al-Araby Zuhaily, Wahbah. al-Fiqh al-Islamy wa Adillatuh. Bairut: Dar al-Fikr, 1997 